\title{
DÜBLIN
}

Technological University Dublin

ARROW@TU Dublin

\section{Isolation, Purification and Characterization of a Novel Solvent Stable Lipase From Pseudomonas Reinekei}

\author{
Barry Ryan \\ Technological University Dublin, barry.ryan@tudublin.ie \\ Priyanka Priyanka \\ Technological University Dublin, D15127729@mydit.ie \\ Gemma K. Kinsella \\ Technological University Dublin, gemma.kinsella@tudublin.ie
}

See next page for additional authors

Follow this and additional works at: https://arrow.tudublin.ie/schfsehart

Part of the Biochemistry, Biophysics, and Structural Biology Commons

\section{Recommended Citation}

Ryan, B., Priyanka, P., Kinsella, G. and Henehan, G. (2019) Isolation, purification and characterization of a novel solvent stable lipase from Pseudomonas reinekei. Protein Expression and Purification, 153, 121-130 (2019)

This Article is brought to you for free and open access by the School of Food Science and Environmental Health at ARROW@TU Dublin. It has been accepted for inclusion in Articles by an authorized administrator of ARROW@TU

Dublin. For more information, please contact

arrow.admin@tudublin.ie, aisling.coyne@tudublin.ie, gerard.connolly@tudublin.ie.

Funder: Technological University Dublin

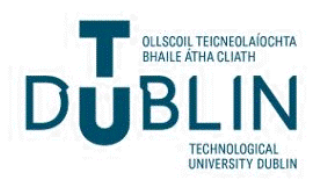




\section{Authors}

Barry Ryan, Priyanka Priyanka, Gemma K. Kinsella, and Gary T. Henehan

This article is available at ARROW@TU Dublin: https://arrow.tudublin.ie/schfsehart/296 


\title{
Isolation, purification and characterization of a novel solvent stable lipase from Pseudomonas reinekei
}

\author{
Priyanka Priyanka*, Yeqi Tan*, Gemma Kinsella*, Gary T. Henehan*, Barry J. Ryan*\# \\ *Dublin Institute of Technology \\ \# Corresponding Author (barry.ryan@dit.ie; Ph: 00353-1-4024379, Fax: +353 1402 3000)
}

\begin{abstract}
The Pseudomonas sp. have been long recognized for their exogenous lipolytic activities yet the genus still contains a lot of unexplored strains. Due to the versatile metabolic machinery and their potential for adaptation to fluctuating environmental conditions Pseudomonas sp. are of great interest for biotechnological applications. In this study, a new extracellularly produced lipolytic enzyme from Pseudomonas sp. (P. reinekei) was purified and characterized. The production of lipase from P. reinekei (H1) was enhanced 10-fold by optimizing the nitrogen source. The $50 \mathrm{kDa} H 1$ lipase was purified using negative and positive mode anion exchange chromatography. The purified lipase was active over a broad pH range (5.0-9.0) and was stable for $24 \mathrm{~h}$ at $40^{\circ} \mathrm{C}$. The lipase showed significant stability, and indeed activation, in the presence of organic solvents with $\log P \geq 2.0$. These features render this lipase of interest as a biocatalyst for applications such as biodiesel production, detergent formulations and biodegradation of oil in the environment.
\end{abstract}

Keywords: Pseudomonas, lipase, chromatography, solvent stability, fermentation

\section{Introduction}

Lipases also known as serine hydrolases are ubiquitous enzymes that belong to the triacylglycerol ester hydrolase family (EC 3.1.1.3). They are also termed carboxylesterases, since they can catalyse the hydrolysis (and synthesis) of long-chain triglycerides. They were first identified in pancreatic juice by Bernard in 1856 [1]. Later in 1901, their presence was observed in the bacterial genus Bacillus [2], and this initiated an ongoing exploration of lipase-producing microbes of which Candida, Geotrichum, Rhizopus, Bacillus, Pseudomonas, Burkholderi and Streptomyces are the most studied [3]. They have been widely used for synthesis of novel compounds in so called biocatalytic processes.

Enzyme catalysed water-based transformations can result in unwanted side reactions such as hydrolysis, racemization, polymerization and decomposition; and may have lower yields due to solubility of substrates/products [4]. Hence, the biocatalytic environment, from a processing and economic viewpoint, has shifted researchers' interest from aqueous to a non-aqueous environment [5]. Organic solvents are the most commonly used non-aqueous media for bio-catalysis [6]. However, enzymes may be inactivated, or denatured, in organic solvents thereby limiting their use in some cases [4]. Despite this drawback many 
industrial processes such as the production of biodiesel, biopolymers, cosmetics and pharmaceuticals still employ enzymes in non-aqueous environments. Solvent stable lipases are one of the leading biocatalysts in non-aqueous environment due to their unique property of catalysing a wide variety of useful

37 transformations. The benefits of non-aqueous biocatalysis have encouraged researchers to discover, or 38 engineer, enzymes that are stable in non-aqueous environment. In this study, the biodiscovery, 39 purification and characterisation of a novel solvent stable lipase from Pseudomonas reinekei is described.

40 This novel enzyme will be of interest for biocatalytic applications in non-aqueous media.

\section{Materials and methods}

\section{Chemicals and materials}

43 Q-Sepharose high performance (HP) resin was purchased from GE Healthcare. All other chemicals were 44 analytical grade and were purchased from Sigma-Aldrich.

\section{$45 \quad$ Enzyme assay}

\section{Plate assay}

47 Rhodamine B agar plates were used for the detection of lipolytic activity from microbial strains. 48 Rhodamine B agar plates were prepared by using the Kouker and Jaeger Method [7].

$50 p$-NPP ( $p$-Nitrophenyl palmitate) was used as the substrate for the estimation of lipase activity as per 51 Glogauer and colleagues [8]. Lipase activity was measured after $30 \mathrm{mins}$ of incubation at $28^{\circ} \mathrm{C}$.

\section{Zymogram assay}

54 Lipolytic activity of proteins separated by Sodium Dodecyl Sulphate-Polyacrylamide gel electrophoresis 55 (SDS-PAGE; non-reducing) was visualised before Coomassie Brilliant Blue staining. After non-reducing 56 electrophoresis, gels were washed twice in 50mM Phosphate buffer saline with $1.5 \% \mathrm{v} / \mathrm{v}$ Triton X-100 at $\mathrm{pH}$ $577.0 \pm 0.2$ for $30 \mathrm{mins}$ at room temperature and were then were treated with freshly prepared $100 \mu \mathrm{M} 4-$ 58 Methylumbelliferyl butyrate (MUF-butyrate) for 10mins [9]. After incubation, activity bands resulting from 59 4-methylumbelliferyl (MUF) liberation were visualised under UV illumination.

60 
Soil samples collected from the Wicklow mountains in Ireland from various locations were enriched in enrichment media [10] for 72 hours at $28^{\circ} \mathrm{C}, 200 \mathrm{rpm}$. The supernatant of the enriched samples were serially diluted $\left(10^{-1}\right.$ to $\left.10^{-11}\right)$ with autoclaved double distilled water $\left(\mathrm{ddH}_{2} \mathrm{O}\right) .100 \mu$ of each diluted sample was spread on Rhodamine B plates and incubated at $28^{\circ} \mathrm{C}$ for 48 hours. Lipase producing colonies were aseptically picked and were sub-cultured on LB agar plates at $28^{\circ} \mathrm{C}$ to isolate pure colonies. The stability of lipase producing cultures in different solvents was determined by a plate-overlay method [11] against various solvents ranging from $\log \mathrm{P}<0.2$ to $\log \mathrm{P}>2$. Lipolytic strains stable in multiple solvents were 16S rRNA sequenced (Eurofins, Germany).

\section{Lipase production}

\section{Fermentation time and inoculum percentage}

$1 \%$ to $15 \%(\mathrm{v} / \mathrm{v})$ of an overnight grown culture in LB media was added to basal lipase production media containing $50 \mathrm{~g} / \mathrm{L}$ bacteriological peptone, $2 \mathrm{gm} / \mathrm{L}$ sodium chloride, $0.4 \mathrm{gm} / \mathrm{L}$ magnesium sulfate, $0.5 \mathrm{gm} / \mathrm{L}$ ammonium sulfate, $0.3 \mathrm{gm} / \mathrm{L}$ dipotassium hydrogen phosphate, $0.03 \mathrm{gm} / \mathrm{L}$ potassium hydrogen phosphate and $10 \mathrm{~g} / \mathrm{L}$ olive oil at $\mathrm{pH} 7.0 \pm 0.2$. After every $24 \mathrm{hrs}$ of fermentation, cell free supernatant was analysed for lipolytic activity by the spectrophotometer assay.

Nitrogen source and percentage

$1 \% \mathrm{w} / \mathrm{v}$ of different nitrogen sources (bacteriological peptone, tryptone, yeast extract, ammonium sulfate, $L$-Lysine and $L$-Arginine individually) were used as a substitute to $50 \mathrm{~g} / \mathrm{L}$ peptone in the basal lipase production media. After screening the best nitrogen source responsible for maximum lipase production was further explored a different concentration $(0.25-5 \% \mathrm{w} / \mathrm{v})$ to supplement the basal production media.

\section{pH of production media}

The $\mathrm{pH}$ of the production media, with the optimised nitrogen source and concentration, was adjusted between $5.0( \pm 0.2)$ to $9.0( \pm 0.2)$ to identify the optimum production $\mathrm{pH}$.

\section{Purification}

With the optimized fermentation conditions, cell free supernatant was harvested by centrifugation at $4^{\circ} \mathrm{C}$, $5000 \mathrm{xg}$ for $20 \mathrm{mins}$. The supernatant was filtered through a $1.2 \mu \mathrm{m}$ pre-filter, followed by $0.45 \mu \mathrm{m}$ filter. The filtered supernatant was dialysed at 1:20 ratio in $10 \mathrm{mM}$ Tris- $\mathrm{HCl}$ buffer at $\mathrm{pH} 9.0( \pm 0.2)$ in $12 \mathrm{kDa}$ cut off dialysis membrane. Lipase was purified from the dialysate using two step anion exchange chromatography with Q-Sepharose High Performance resin $(6 \mathrm{~cm} \times 1.5 \mathrm{~cm})$. The first purification step 
was carried out at flow through mode; pre-equilibrated with $10 \mathrm{mM}$ Tris- $\mathrm{HCl}$ at $\mathrm{pH} 9.0( \pm 0.2)$; the second purification with bind and elute mode; pre-equilibrated with $10 \mathrm{mM}$ Tris- $\mathrm{HCl} \mathrm{pH} 9.0( \pm 0.2)$ containing $250 \mathrm{mM} \mathrm{NaCl}$. The flow though from first column was collected and before using it for lipase purification from the second anion exchange chromatography $250 \mathrm{mM}$ of $\mathrm{NaCl}$ was added to it. Purified lipase was collected from second anion exchange chromatography when a step elution of $500 \mathrm{mM} \mathrm{NaCl}$ was performed.

Crude and purified lipase fractions were analysed on $12 \%(\mathrm{v} / \mathrm{v})$ reducing and non-reducing, SDS-PAGE. Protein bands were checked for lipolytic activity by zymogram assay and were also visualised by Coomassie Brilliant Blue staining. The relative molecular mass was calculated by comparing with the molecular weight marker (14.4kDa- 116kDa, Pierce ${ }^{\mathrm{TM}}$ Unstained Protein marker).

\section{Stability Studies/Characterisation}

The stability of purified lipase was monitored over $\mathrm{pH} 3.0-10.0$ at $28^{\circ} \mathrm{C}$ using the following buffers: $50 \mathrm{mM}$ of Glycine- $\mathrm{HCl}(\mathrm{pH} 3.0,4.0), 50 \mathrm{mM}$ of Tris-Acetate $(\mathrm{pH} 5.0,6.0), 50 \mathrm{mM}$ of Tris- $\mathrm{HCl}(\mathrm{pH} \mathrm{7.0}$, $8.0,9.0)$ and $50 \mathrm{mM}$ of Borate Buffer $(\mathrm{pH} 10.0)$ and subsequent relative activity was expressed as percentage to highest activity. The effect of temperature at $20,30,40,50,60,70$ and $80^{\circ} \mathrm{C}$ was determined by pre-incubating the purified lipase solution at the relevant temperature for 1.0 hour and 24 hours and subsequent residual activity was expressed as a percentage of the activity at $4^{\circ} \mathrm{C}$. The thermal half-life $\left(\mathrm{T}_{1 / 2}\right)$ of lipase was determined by incubating the enzyme solution at $45^{\circ} \mathrm{C}$ for 1.5 hours and analysing for lipase activity by withdrawing samples at different intervals. Lipase stability in organic solvents was investigated by gently mixing purified lipase solution and the selected solvent in screw cap glass vials under continuous mixing at both $28^{\circ} \mathrm{C}$ and $40^{\circ} \mathrm{C}$. Similarly, the effect of additives (metal ions, enzyme inhibitors and surfactants) on purified lipase was estimated at $28^{\circ} \mathrm{C}$ and $40^{\circ} \mathrm{C}$. Enzyme activity is represented as a \% residual activity and was measured relative to control (enzyme solution without any solvents/additives at same condition). The steady state Michaelis-Menten kinetic constants of $\mathrm{K}_{\mathrm{m}}$ and $\mathrm{V}_{\max }$ were determined by Lineweaver-Burk plot using the reaction rate at varying substrate concentrations ( $p$ NP-Palmitate) under standard assay conditions. The catalytic constant ( $\left.\mathrm{K}_{\text {cat }}\right)$ was calculated by using $\mathrm{V}_{\max }$, molecular weight and concentration of the enzyme. Lipolytic activity for all the characterisation trials (except substrate specificity) was estimated using spectrophotometric assay with $p$ nitrophenyl palmitate ( $p$-NPP) as substrate.

\section{Results and discussion}

Isolation and identification of solvent tolerant lipase producing strain: 

were found to be stable in methanol, ethanol, n-hexane, heptane and cyclohexane by plate overlay method [11]. 16S rRNA sequencing of these strains identified one of the lipolytic cultures as Pseudomonas reinekei (P. reinekei), designated $\mathrm{H} 1$. The Pseudomonas genus demonstrates a great deal of metabolic diversity and attracts attention for industrial and environmental biocatalysis [12]. Figure 1 illustrates stability of Pseudomonas reinekei and its lipase respectively towards $n$-heptane by plate overlay method.

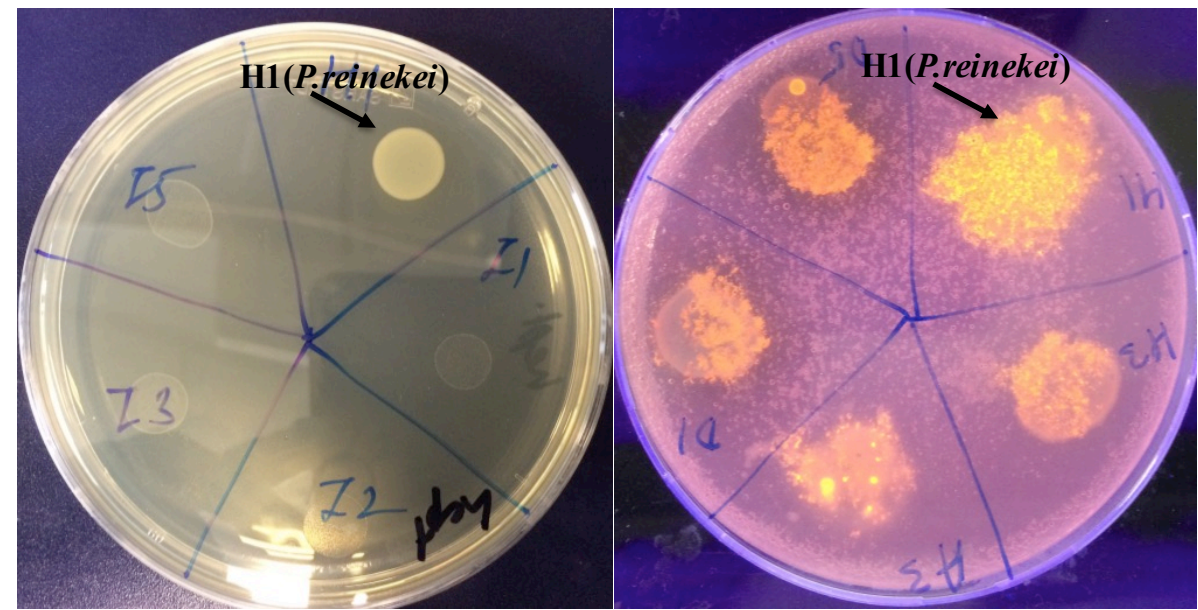

(A)

(B)

Figure 1: Plate over lay method: (A) LB agar plates treated with $n$-heptane. The presence of growth indicated stability of the P. reinekei (H1) towards the organic solvent ( $n$-heptane in the figure). (B) Stability of extracellular crude lipase towards $n$-heptane visualized by UV-illumination of Rhodamine B agar plates treated with $n$-heptane.

\section{Lipase production}

Production of lipases is known to be affected by media composition as well as factors like fermentation time, initial inoculum level, nitrogen source, $\mathrm{pH}$, temperature etc. [13] and these were investigated following a one-factor at a time optimisation approach [14].

\section{Fermentation time and Inoculum percentage}

The percentage of inoculum (i.e. the initial cell count) during the fermentation process plays an important role in lipase production. The finite volume of a culture medium results in limited nutrients and the rate of nutrient consumption is dependent on bacteria cell population/growth stage [15]. Maximum lipase activity for P. reinekei (H1) was obtained with $15 \%$ (v/v) inoculum after 6 days of fermentation (Figure 2). The onset of lipase production is organism-specific but, in general, lipases are released during late logarithmic or stationary phase of growth [16]. Cultivation periods from 5.0 hours to 168 hours have been reported as optimal for different lipase producing organisms. Lipases from Serratia marcesecens [17] and 

fermentation respectively.

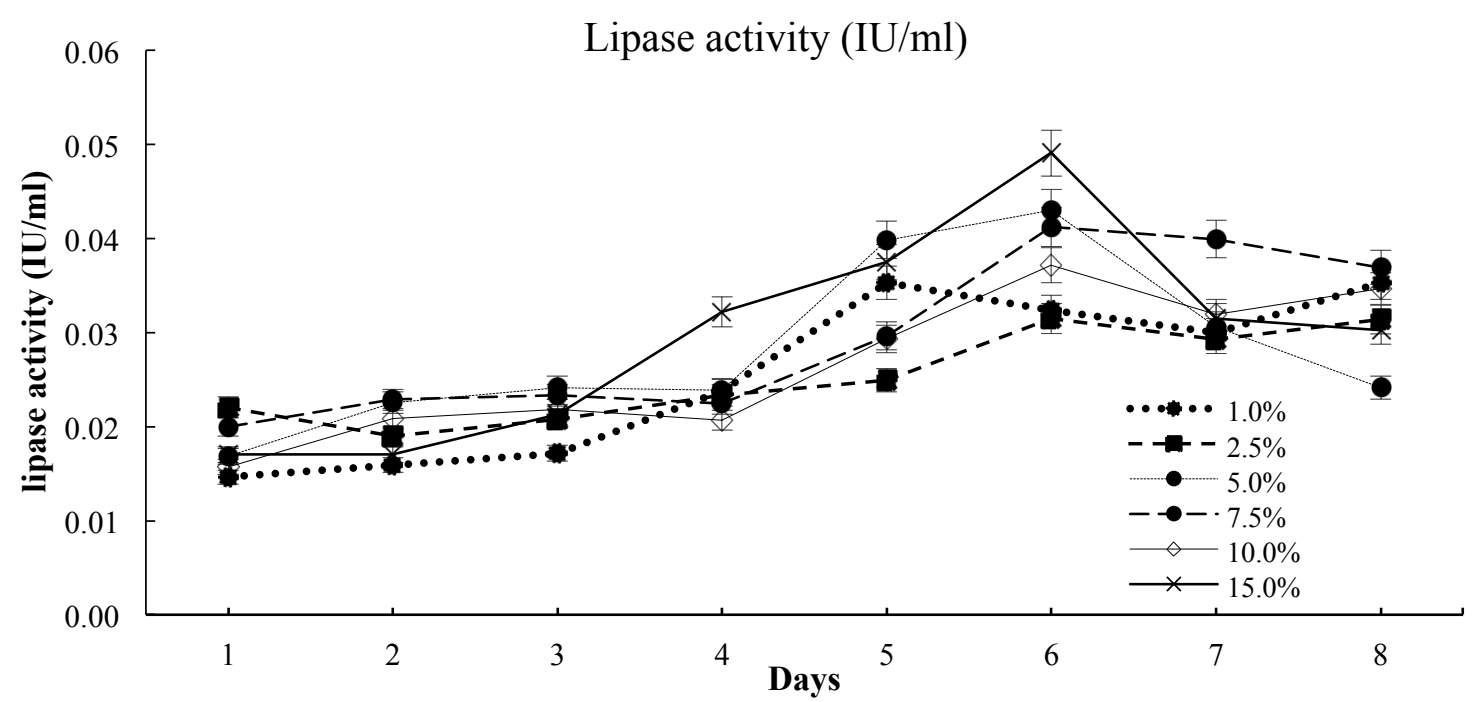

Figure 2: The effect of percentage inoculums $(1-15 \% \mathrm{v} / \mathrm{v})$ on lipase production as estimated via spectrophotometric activity assay. This shake flask experiment was performed in basal lipase production media at $28^{\circ} \mathrm{C}$ with $200 \mathrm{rpm}$ continuous shaking over a period of 8 days. Data represented here are the mean of three independent determinants with error bars as standard deviation.

\section{Nitrogen source}

For the lipase from $P$. reinekei $(\mathrm{H} 1)$, a $1 \%(\mathrm{w} / \mathrm{v}$, or $68 \mathrm{mM}) L$-Lysine supplement resulted in a significant ( $\mathrm{P} \leq 0.05$, t-test) increase in lipase production to $0.46 \pm 0.023 \mathrm{IU} / \mathrm{mL}$ and was the best nitrogen source of all the nitrogen sources examined (Figure 3). Both organic and inorganic nitrogen sources have traditionally been used for lipase production. Media supplementation with specific amino acids; such as alanine, glycine, lysine and serine, have previously been shown to stimulate lipase production in Streptococcus faecalis [19]. For example, tryptone, combined with Lysine, was the most effective inducer for lipase production in Pseudomonas fluorescens [20]. Similarly, lipase production was enhanced by the presence of arginine, lysine, aspartic acid and glutamic acid for Pseudomonas fragi [21].

Increased $L$-Lysine concentrations (above $1 \%, \mathrm{w} / \mathrm{v}$ ) resulted in a decrease in lipase production. There was no significant difference $(\log \mathrm{P}>0.05$, t-test) in lipase concentration for $0.25 \%, 0.5 \%$ and $1 \%(\mathrm{w} / \mathrm{v}) L$ Lysine (Figure 4). 


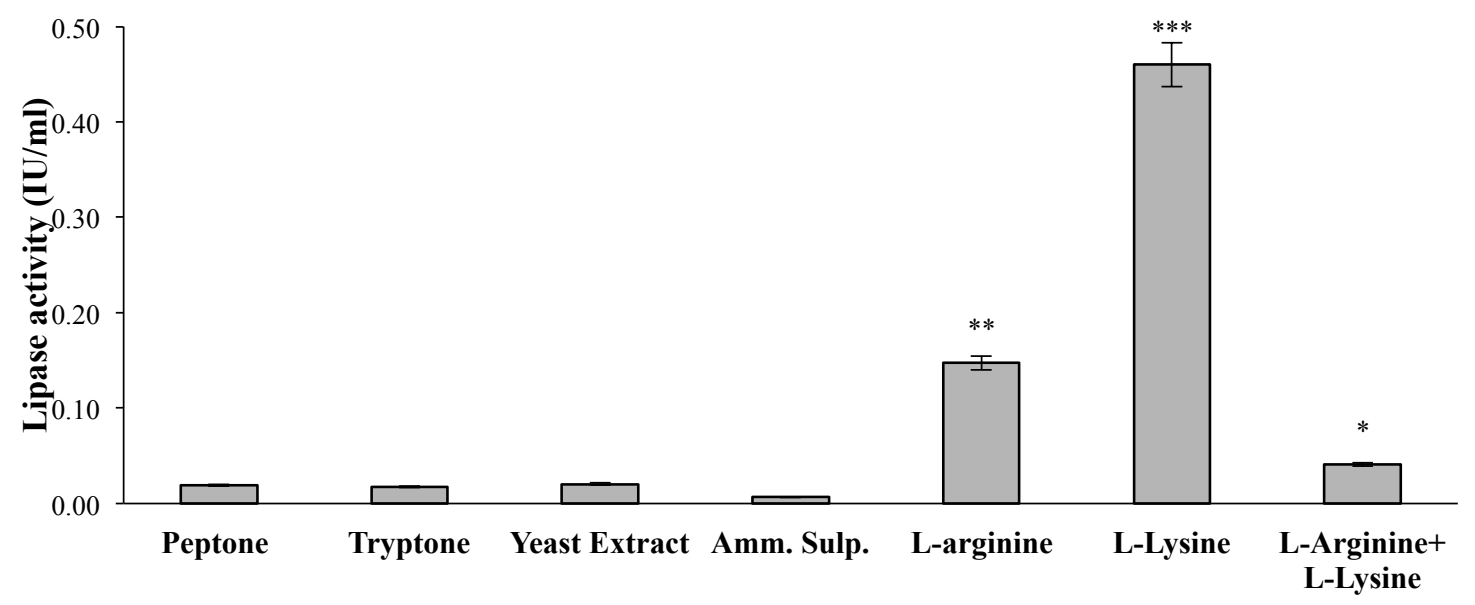

Figure 3: Influence of Nitrogen supplementation on Lipase production. Media supplementation optimization was performed by replacing the nitrogen source in basal lipase production media (without peptone) with $1 \%(\mathrm{w} / \mathrm{v})$ of different nitrogen sources. A $15 \%(\mathrm{v} / \mathrm{v})$ of inoculum was used for lipase production $\left(28^{\circ} \mathrm{C}\right.$, for 6 days under continuous shaking at $200 \mathrm{rpm})$. Amm sulp. represents $1 \%(\mathrm{w} / \mathrm{v})$ of ammonium sulfate; while $L$-Arginine $\& L$-Lysine represent lipase producing media containing $1 \%(\mathrm{w} / \mathrm{v})$ of both $L$-Arginine and $L$-Lysine The data represented here are the mean of three independent experiments with standard deviations shown as error bars $\left(* \mathrm{P} \leq 0.05,{ }^{*} \mathrm{P} \leq 0.01\right.$, $* * * \mathrm{P} \leq 0.001$ represents significant, very significant and extremely significant difference based on t-test)

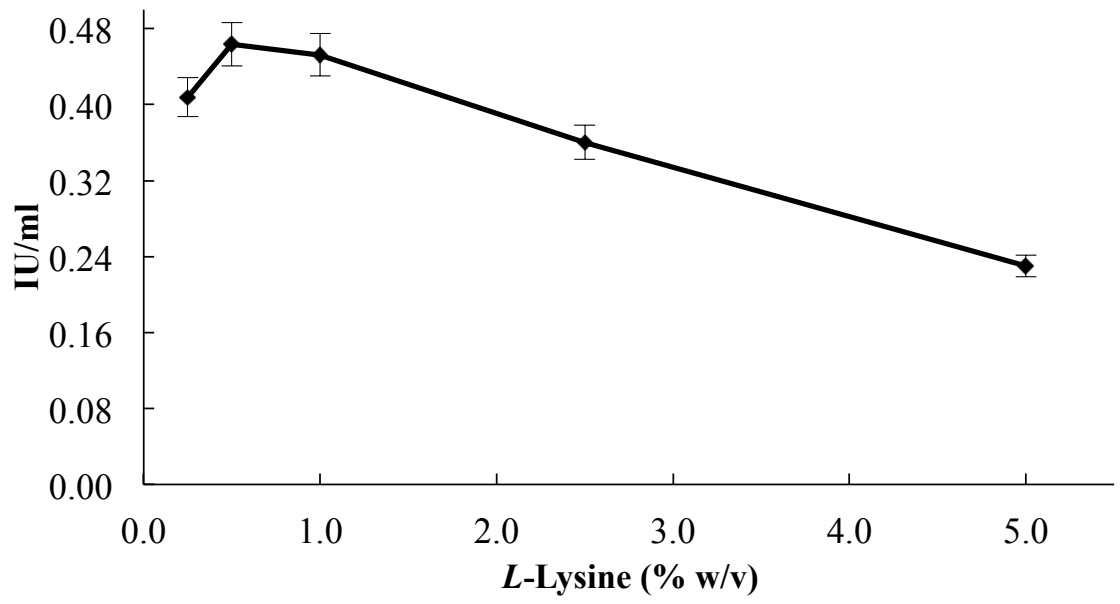

Figure 4: Influence of level of Lysine supplementation on Lipase production. Media supplementation optimization experiment was performed with different $\%(\mathrm{w} / \mathrm{v})$ of $L$-lysine in the production media (basal media without peptone). $15 \%(\mathrm{v} / \mathrm{v})$ of inoculum was used for lipase production $\left(28^{\circ} \mathrm{C}\right.$, for 6 days under continuous shaking at $200 \mathrm{rpm})$. No statistically significant difference was observed in lipase activity at $0.5 \%(\mathrm{w} / \mathrm{v})$ and $1 \%(\mathrm{w} / \mathrm{v})$ of LLysine. The data represented here are the mean of three independent experiments with standard deviations noted as error bars.

\section{Influence of media $\mathrm{pH}$}

$\mathrm{pH}$ plays a significant role in enzyme stability through maintaining an enzyme's three-dimensional structure required for its biological activity [22]. Enzymes remain metabolically active at a favourable $\mathrm{pH}$ range during fermentation. The maximum lipase production $(0.46 \pm 0.02 \mathrm{IU} / \mathrm{mL})$ was achieved when the initial $\mathrm{pH}$ of the production media was $6.5( \pm 0.2)$. Above $\mathrm{pH} 7.0( \pm 0.2)$, there was a significant reduction 
( $\mathrm{P} \leq 0.05$, t-test) in lipase production (Figure 5). A pH $7.0( \pm 0.2)$ was found to be optimum for lipase 189 production in Pseudomonas gessardii [23], P. fluorescens [24] and P. aeruginosa [25]. In comparison, 190 Pseudomonas putida 922 produced maximum lipase after 48 hours of incubation in a production media at $191 \mathrm{pH} 10[26]$.

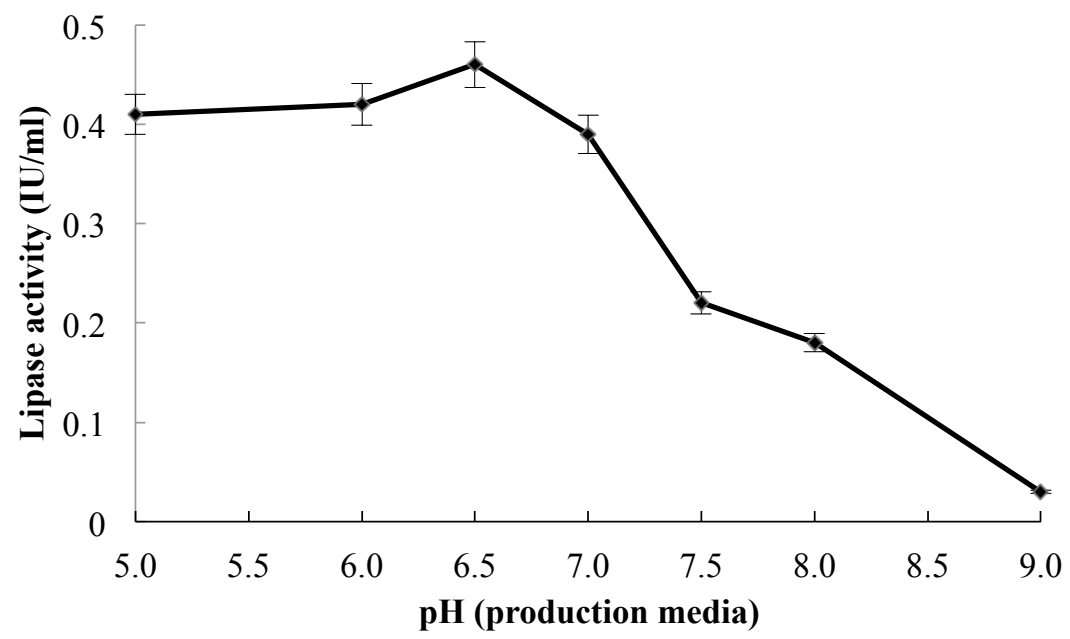

193 Figure 5: Influence of initial media $\mathrm{pH}$ on lipase production. Optimization was achieved by adjusting the $\mathrm{pH}$ of 194 lipase producing media containing $1 \%(\mathrm{w} / \mathrm{v})$ of $L$-Lysine. A $15 \%(\mathrm{v} / \mathrm{v})$ inoculum was used for lipase production $195\left(28^{\circ} \mathrm{C}\right.$, for 6 days under continuous shaking at $\left.200 \mathrm{rpm}\right)$. The data represented here are the mean of three independent 196 experiments, with standard deviations noted as error bars.

\section{Purification of P. reinekei Lipase}

199 The isolation of the lipase from the optimized fermentation parameters was achieved by a two-step procedure

200 (Table 1). The first purification column; an anion exchange Q-Sepharose HP (negative mode chromatography)

201 removed contaminant proteins from the lipase preparation. The second chromatography step (positive mode

202 chromatography; bind and elute), an anion exchange on Q-Sepharose HP resulted in isolation of $50 \mathrm{kDa}$

203 lipase (Figure 6). 
Table 1: The purification of lipase from P. reinekei $(\mathrm{H} 1)$ by two-step purification. Anion exchanger Q-Sepharose HP was used as negative (chromatography 1) and positive (chromatography 2) mode of purification to achieve an overall yield of $13.72 \%, 4.23 \mathrm{IU} / \mathrm{mg}$ specific activity and a 4.65 fold purification.

\begin{tabular}{|l|l|l|l|l|l|}
\hline Purification step & $\begin{array}{l}\text { Total } \\
\text { activity (IU) }\end{array}$ & $\begin{array}{l}\text { Total protein } \\
\text { (mgs) }\end{array}$ & $\begin{array}{l}\text { Specific } \\
\text { activity } \\
\text { (IU/mg) }\end{array}$ & $\begin{array}{l}\text { Purification } \\
\text { (fold) }\end{array}$ & $\begin{array}{l}\text { Yield } \\
(\%)\end{array}$ \\
\hline Cell free supernatant & 75.1 & 82.48 & 0.91 & 1 & 100 \\
\hline Dialysate & 64.2 & 82.06 & 0.79 & 0.98 & 97.13 \\
\hline Chromatography 1 & 49.4 & 47.60 & 1.04 & 1.14 & 67.66 \\
\hline Chromatography 2 & 6.8 & 1.60 & 4.23 & 4.65 & 13.72 \\
\hline
\end{tabular}

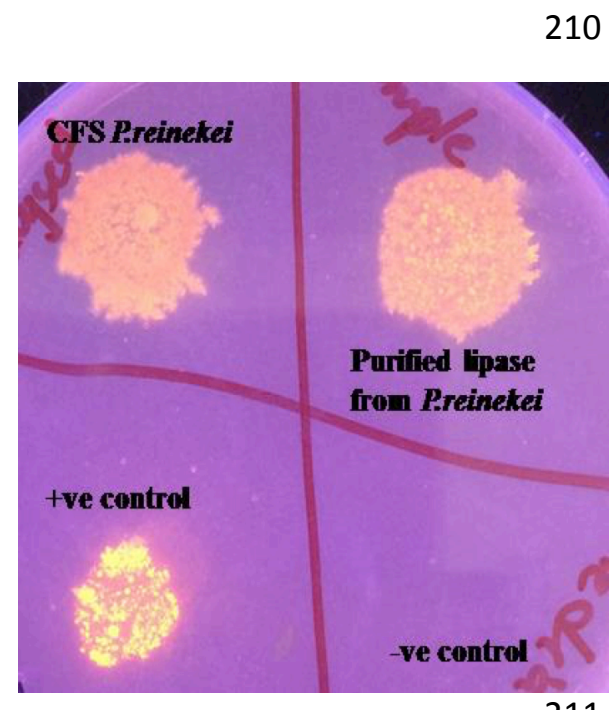

211

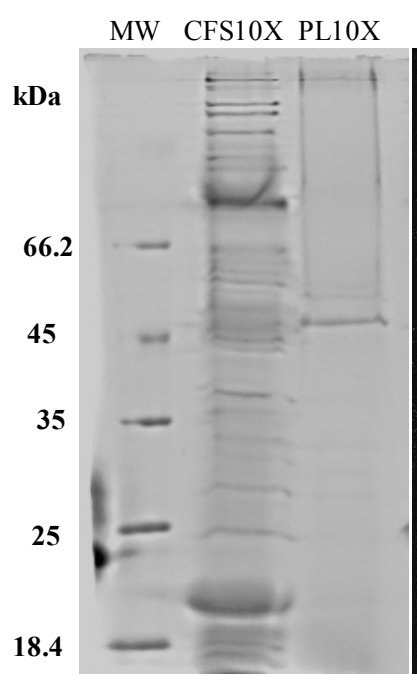

(B)

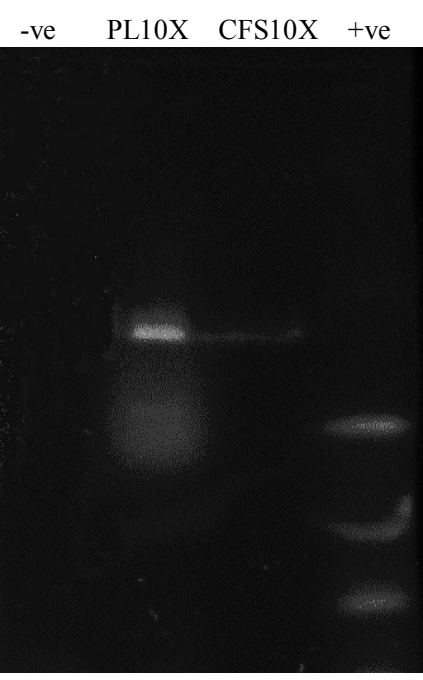

(C)
(A)

Figure 6: (A) Rhodamine B agar plate representing the presence of lipolytic activity in purified lipase. CFS: Cell free supernatant from P.reinekei, +ve control: M.meihei lipase, -ve control: Bovine serum albumin. (B) 12\% (v/v) non-reducing SDS-PAGE gel Stained with Coomassie Brilliant Blue. Lane 1: molecular weight marker, lane 2: Cell Free Supernatant; lane 3: Purified Lipase (C) Zymogram of 12\% (v/v) non-reducing SDS-PAGE. Lane 1: Negative control (Bovine Serum Albumin); Lane 2: Cell Free Supernatant; Lane 3: Purified Lipase; Lane 4: lipase from M.meihei as positive control. The estimated size of purified lipase was $\sim 50 \mathrm{kDa}$.

Previous studies have shown sorbitol and other polyols to effectively reduce or inhibit aggregation of IgG solutions [27]. Therefore, to enhance the stability of lipase and to avoid precipitation due to aggregation $5 \%(\mathrm{w} / \mathrm{v})$ sorbitol was added to purified lipase sample with no effect on the characteristics of the purified lipase. 
Significant loss of activity was seen at $\mathrm{pH} 3.0( \pm 0.2), 4.0( \pm 0.2)$ and $\mathrm{pH} 10( \pm 0.2)$; conversely $>90 \%$ relative activity was observed between $\mathrm{pH} 5.0( \pm 0.2)$ to $8.0( \pm 0.2)$ (Figure 7). Generally, Pseudomonas lipases have neutral or alkaline $\mathrm{pH}$ optima [28], however $P$. gessardii lipase had an acidic optimum at $\mathrm{pH}$ 5.0 and was found to be active even at $\mathrm{pH} 2.0$ [29]. Given that the purified from P. reinekei (H1) was stable from $\mathrm{pH}$ 5.0-9.0 it could prove advantageous in application areas such as detergents, leather tanning and fine chemicals manufacture [30]. Furthermore, an optimal pH of 5.0 makes this lipase ideal for oleochemical and food industries, as well as for the hydrolysis or modification of triacylglycerols to improve nutritional properties of food [31].

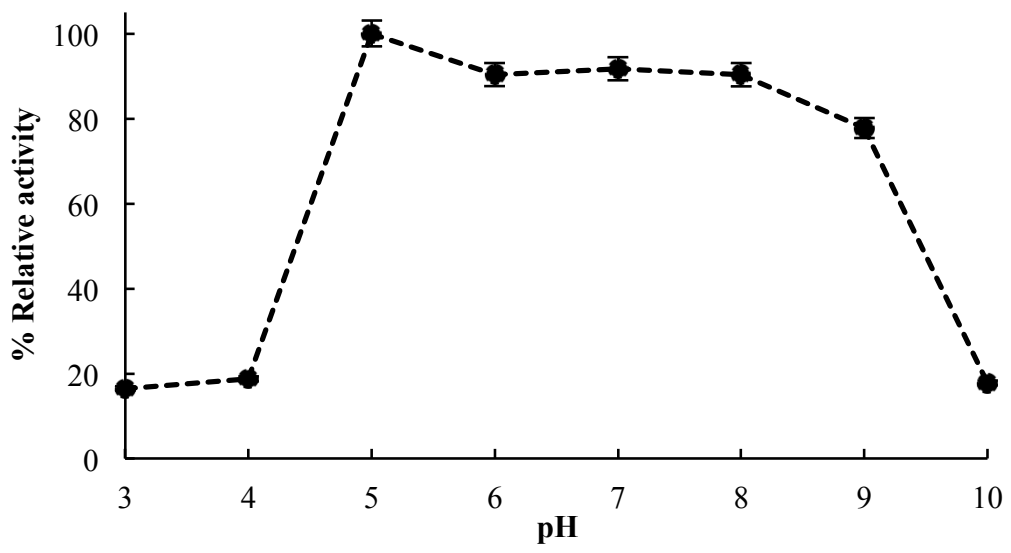

Figure 7: The relative activity of purified P. reinekei (H1) lipase was measured after 24hours incubation at $28^{\circ} \mathrm{C}$ in the presence of different $\mathrm{pH}$ buffers ( $\mathrm{pH}$ 3.0-10.0). The relative lipase activity was measured by spectrophotometric assay. The data represent the mean of three independent experiments and the standard deviations are noted as error bars.

\section{Thermostability}

Optimum temperature for lipolytic activity of purified lipase from P.reinekei using p-NPP spectrophotometer assay was $35^{\circ} \mathrm{C}$ (Figure 8). Purified lipase from P. reinekei lost $70 \%$ of its initial activity at temperatures greater than $50^{\circ} \mathrm{C}$ within one hour of incubation (Figure 9). However, the lipase retained $90 \%$ of activity at $40^{\circ} \mathrm{C}$ after 24hours. Lipases from Pseudomonas species have broad temperature optima from $4{ }^{\circ} \mathrm{C}$ to $90^{\circ} \mathrm{C}$. Lipase from Pseudomonas sp. PF 16 had an optimum temperature of $4^{\circ} \mathrm{C}$ [32]; while lipase from Pseudomonas sp. AG-8 showed optimum activity at $45^{\circ} \mathrm{C}$ [33]. The inter-connection between the habitat of 
micro-organism isolated and the enzyme properties [34] could be a possible reason for explaining the lower thermostability of $P$. reinekei $(\mathrm{H} 1)$ lipase. As the soil sample for $\mathrm{H} 1$ isolation was from temperate

250 environmental conditions, lower thermostability of enzymes was expected. However, thermostability is a 251 desirable characteristic for enzymes used in applications at high temperatures; the same can be achieved by 252 protein engineering such as physical immobilization, chemical modification and crosslinking [35].

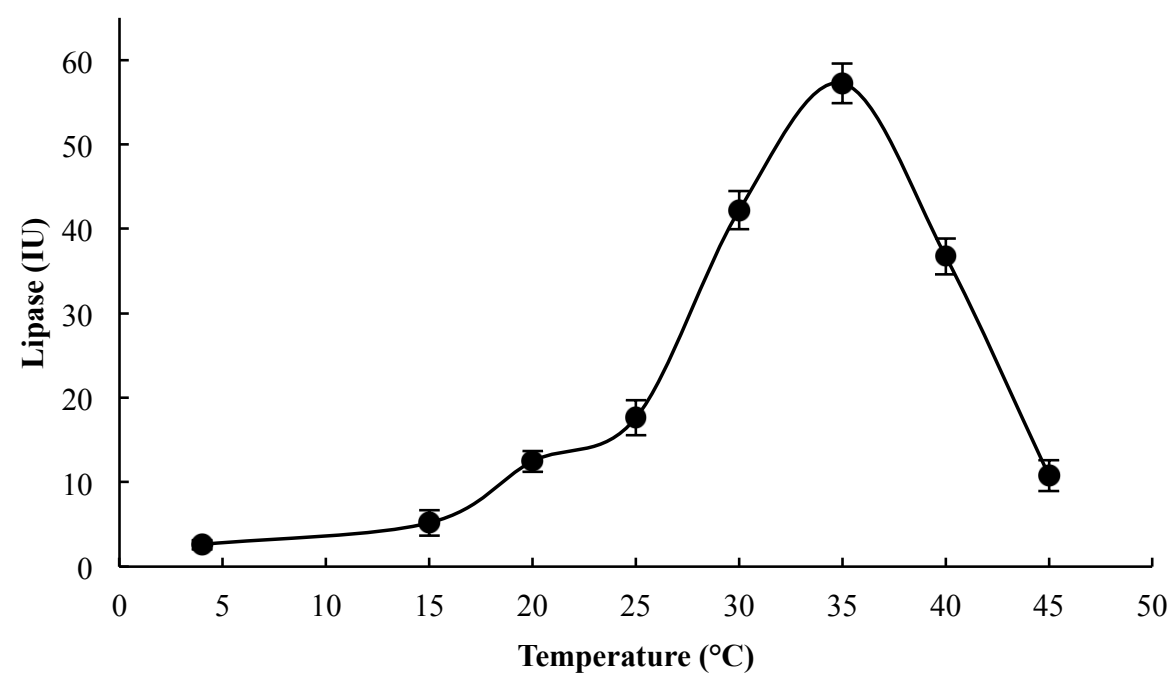

Figure 8: The optimum temperature for lipolytic activity of purified lipase was investigated by incubating the enzyme-substrate solution at various temperatures $\left(4,15,20,25,30,35,40\right.$ and $\left.45^{\circ} \mathrm{C}\right)$ for 30 mins. Activity of lipase (IU) was calculated. The data represented are the mean of three independent experiments and the standard deviations are noted as error bars.

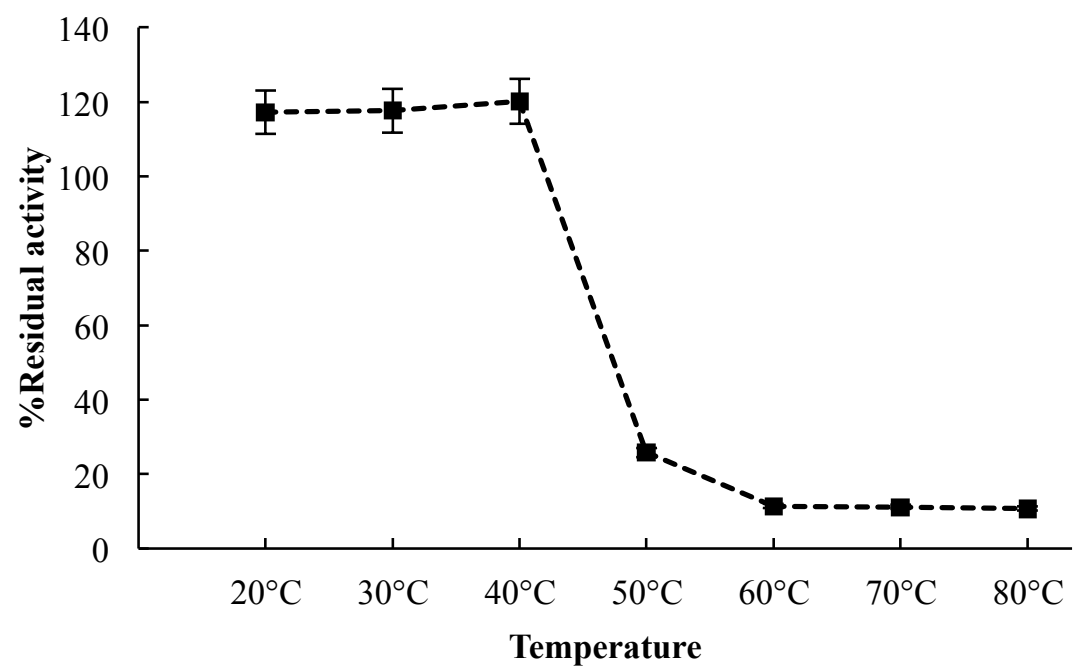

Figure 9: The thermal stability of purified lipase was investigated by incubating the enzyme solution at various temperatures $\left(20,30,40,50,60,70\right.$ and $\left.80^{\circ} \mathrm{C}\right)$ for 1 hour. Residual activity $(\%)$ at each temperature and time point 
264 By first order thermal deactivation, half-life of purified lipase at $45^{\circ} \mathrm{C}$ (Figure 10) was calculated as $89 \mathrm{mins}$ 265 according to eq. (1) and eq. (2) [36].

266

267

268

\section{9}

270

271

272

273

274

275 The presence of $\mathrm{Ca}^{2+}$ and $\mathrm{Mg}^{2+}$ ions has been reported to enhance the hydrolytic activity of lipases [37,38].

276 However, the activity of $P$. reinekei (H1) lipase was unaffected ( $\mathrm{P} \geq 0.05, \mathrm{t}$-test) by the presence of $\mathrm{Ca}^{2+}, \mathrm{Mg}^{2+}$,

$277 \mathrm{~K}^{+}, \mathrm{Na}^{+}$ions irrespective of the incubation temperature. P. reinekei (H1) lipase lost activity in the presence of

278 EDTA, suggesting this it may be a metalloenzyme and EDTA chelated metal ions required for its activity.

279 Lipases from Pseudomonas putida 3SK, Pseudomonas stutzeri, and Pseudomonas sp. DMVR46 were also

280 found to be metalloenzymes [12,39,40]. Significant loss in lipolytic activity ( $\leq 0.05$, t-test) for P. reinekei

281 (H1) lipase was observed in presence of urea. Urea molecules interrupt the intra-chain hydrogen bonds in an

282 enzyme and can cause direct denaturation [41]. However, lipase from Pseudomonas sp. AG-8 [33] and

283 Pseudomonas sp. 42A2 [42] have been shown to be stable in $6.0 \mathrm{M}$ urea. Non-ionic detergents do not interact

284 extensively with the protein surface and are therefore considered mild. Ionic detergents on the other hand, in-

285 particular SDS, bind non-specifically to the enzyme surface, leading to protein unfolding [43]. Interestingly, 
in the presence of $1 \mathrm{mM}(0.028 \% \mathrm{w} / \mathrm{v}) \mathrm{SDS}$, an enhanced activity of the P. reineki (H1) lipase was observed (Table 2). Enhanced activity at $28^{\circ} \mathrm{C}$, coupled with no significant loss in activity at $40^{\circ} \mathrm{C}$, could be explained by the concentration of SDS. Below the Critical Micelle Concentration CMC $\left(8.2 \mathrm{mM}\right.$ or $0.24 \% \mathrm{w} / \mathrm{v}$ at $\left.25^{\circ} \mathrm{C}\right)$ SDS binds to the lid of lipase and activates it by conformational changes and the enzyme requires less interfacial activation [44]. Also, detergents may also alter the hydrophobicity of the enzyme and, therefore, the availability of substrate to the enzyme [45]. The absence of disulphide bonds in the novel P. reinekei lipase was confirmed as no activity loss was noted after incubation in $\beta$-Mercaptoethanol. A similar observation was seen with lipases from Streptomyces bambergiensis OC 25-4 [46] and Pseudomonas aeruginosa BN-1 [47]. Stability in surfactants like Tween, Triton X is desirable for lipases for their potential application in detergent formulations. The lipase from P. reinekei (H1) exhibited good stability towards surfactant and detergents, which enhances its' novel properties and extends its potential application range. The effect of detergents on this enzyme correlates with their hydrophilic/lipophilic balance (HLB), which is defined the detergent distribution between polar and non-polar phases [48]. Thus, non-ionic surfactants with low HLB value (Triton X-100: HLB 13.5; and Tween 80: HLB 15) are less detrimental on activity of lipase in comparison to SDS with a higher HLB of 40.

Table 2: The effect of various metal ions and effector molecules/chemicals $(1 \mathrm{mM})$ on the stability/activity of $P$. reinekei (H1) lipase was investigated and reported by the spectrophotometer assay. The residual activity (\%) was calculated relative to that of enzyme solution at same temperature but in the absence of any additive, after 24 hours of incubation at $28^{\circ} \mathrm{C}$ and $40^{\circ} \mathrm{C}$. The data represented are the mean of three independent experiments and the standard deviations are noted $(* \mathrm{P} \leq 0.05, * * \mathrm{P} \leq 0.01, * * * * \mathrm{P}<0.0001$ represents significant, very significant and extremely significant difference based on t-test)

\begin{tabular}{|l|c|c|}
\hline \multicolumn{1}{|c|}{ Substances } & Residual activity $\left.\pm \mathbf{S D ~} \mathbf{( 2 8}^{\circ} \mathbf{C}\right)$ & Residual activity $\left.\pm \mathbf{S D ~} \mathbf{4 0}^{\circ} \mathbf{C}\right)$ \\
\hline Control & 100 & 100 \\
\hline $\mathrm{Ca}^{2+}$ & $87.25 \pm 3.36^{* *}$ & $98.88 \pm 4.94$ \\
\hline $\mathrm{Mg}^{2+}$ & $95.06 \pm 3.75$ & $105.00 \pm 4.25$ \\
\hline $\mathrm{K}^{+}$ & $95.70 \pm 3.78$ & $106.76 \pm 4.34$ \\
\hline $\mathrm{Na}^{+}$ & $100.48 \pm 4.02$ & $90.87 \pm 4.54^{*}$ \\
\hline EDTA & $26.36 \pm 1.32^{* * * *}$ & $11.60 \pm 1.58^{* * * *}$ \\
\hline$\beta$-Mercaptoethanol & $122.73 \pm 5.14^{* *}$ & $114.98 \pm 5.75^{*}$ \\
\hline Polysorbate 80 & $98.60 \pm 3.93$ & $103.28 \pm 5.16$ \\
\hline Triton X-100 & $100.48 \pm 4.02$ & $90.87 \pm 4.54^{*}$ \\
\hline SDS & $110.48 \pm 4.52^{*}$ & $88.24 \pm 5.41^{* *}$ \\
\hline
\end{tabular}

\section{Effect of Organic solvents}

The application of lipases for bioconversions in an organic solvent system is advantageous from a biotechnological viewpoint. Activity and stability in solvents are considered critical attributes in a lipase. $P$. 
reinekei (H1) lipase showed significant stability in $20 \%(\mathrm{v} / \mathrm{v})$ methanol and ethanol after 24 hours of incubation (Table 3). Few lipases have been reported as stabilized/activated, in hydrophilic solvents; for example, Antarctic Pseudomonas lipase lost only $10 \%$ of its activity in presence of $25 \%$ (v/v) methanol, while showed $101.9 \%$ activity in $25 \%(\mathrm{v} / \mathrm{v})$ ethanol [49]. The activation of lipase in the presence of some hydrophilic organic solvents can be explained by the interactions of certain amino acid residues with the organic solvent, changing the lipase conformation from the closed to the open form, thereby enhancing lipase activity [50]. Alternatively, some lipases are known to be able to maintain an essential hydration layer, due to the presence of surface polar/charged amino acid residues, which interact strongly with water molecules [40]. Hydrophobic organic solvents with higher $\log \mathrm{P}$ (for example, cyclohexane, $n$-hexane, $n$-heptane) possess a reduced ability to strip essential water molecules from the enzyme surface than hydrophilic solvents (low log P). Enhanced lipolytic activity was observed for P. reinekei $(\mathrm{H} 1)$ lipase in the presence of hydrophobic solvents (cyclohexane, $n$-hexane and $n$-heptane). The activation in lipolytic activity of $P$. reinekei lipase by hydrophobic solvents may be due to the interaction of solvent with hydrophobic amino acid residues present in the lid/flap covering the catalytic site of the enzyme, thereby keeping the enzyme in a flexible open conformation and consequently increasing its activity [3]. Similar observations have been noted for a lipase from Pseudomonas stutzeri, where the activity increased to $111 \%$ when it was incubated in $50 \%(\mathrm{v} / \mathrm{v}) n$ hexane at $37^{\circ} \mathrm{C}$ for $30 \mathrm{~min}[40]$.

Table 3: The effect of various organic solvents on the stability of P. reinekei (H1) lipase was investigated and reported by the spectrophotometer assay. Residual activity (\%) was calculated relative to that of enzyme solution at same temperature but no additive after 1 hour and 24 hours of incubation at $28^{\circ} \mathrm{C}$ and $40^{\circ} \mathrm{C}$. The data represented are the mean of three independent experiments and the standard deviations are noted (* $\mathrm{P} \leq 0.05,{ }^{*} * \mathrm{P} \leq 0.01, * * * \mathrm{P} \leq 0.001$, $* * * * \mathrm{P} \leq 0.0001$ represents significant, very significant and extremely significant difference based on t-test).

\begin{tabular}{|c|c|c|c|c|}
\hline \multirow{2}{*}{ Solvent } & \%(v/v) & $\begin{array}{c}\text { \% Residual } \\
\text { activity at } \mathbf{2 8}^{\circ} \mathbf{C} \\
\text { after 1hour }\end{array}$ & $\begin{array}{c}\text { \% Residual } \\
\text { activity at } \mathbf{4 0}^{\circ} \mathbf{C} \\
\text { after } \mathbf{1 h o u r}\end{array}$ & $\begin{array}{c}\text { \% Residual } \\
\text { activity at } 28^{\circ} \mathbf{C} \\
\text { after 24hours }\end{array}$ \\
\hline \multirow{2}{*}{ Methanol } & 10 & $96.24 \pm 4.81$ & $97.19 \pm 4.81$ & $92.71 \pm 4.63$ \\
\cline { 2 - 5 } & 20 & $90.19 \pm 4.51$ & $69.02 \pm 3.45^{* * *}$ & $97.86 \pm 4.80$ \\
\hline Ethanol & 10 & $97.57 \pm 4.81$ & $82.86 \pm 4.12^{* *}$ & $92.27 \pm 4.61$ \\
\cline { 2 - 5 } & 20 & $87.90 \pm 4.39^{*}$ & $37.77 \pm 2.19^{* * * *}$ & $92.07 \pm 4.60$ \\
\hline Cyclohexane & 50 & $243.64 \pm 5.81^{* * * *}$ & $198.14 \pm 7.81^{* * * *}$ & $193.28 \pm 6.88^{* * * *}$ \\
\hline Hexane & 50 & $138.72 \pm 7.81^{* * * *}$ & $197.34 \pm 8.82^{* * * *}$ & $275.95 \pm 7.56^{* * * *}$ \\
\hline Heptane & 50 & $181.14 \pm 9.05^{* * *}$ & $192.66 \pm 9.13^{* * * *}$ & $324.37 \pm 4.81^{* * * *}$ \\
\hline
\end{tabular}

\section{Enzyme Kinetics}

The kinetics of the purified lipase from $P$. reinekei was studied using $p$ NP-palmitate as the substrate of choice at $28^{\circ} \mathrm{C}$. A Lineweaver Burk plot (Figure 11) was used to calculate the kinetic parameters $\mathrm{V}_{\max }, \mathrm{K}_{\mathrm{m}}$ 
and $\mathrm{K}_{\text {cat }}$ and were estimated to be $3.41 \pm 0.17 \mathrm{mmol} / \mathrm{min} / \mathrm{mg}, 0.48 \pm 0.02 \mathrm{mM}$ and 2601.66 respectively. Low $\mathrm{K}_{\mathrm{m}}$ of $P$. reinekei lipase indicates a high affinity of this enzyme towards $p$ NP-Palmitate. In this study the high $\mathrm{K}_{\text {cat }}$, coupled with low $\mathrm{K}_{\mathrm{m}}$, values for P. reinekei (H1) lipase are beneficial both from economical and application perspective.

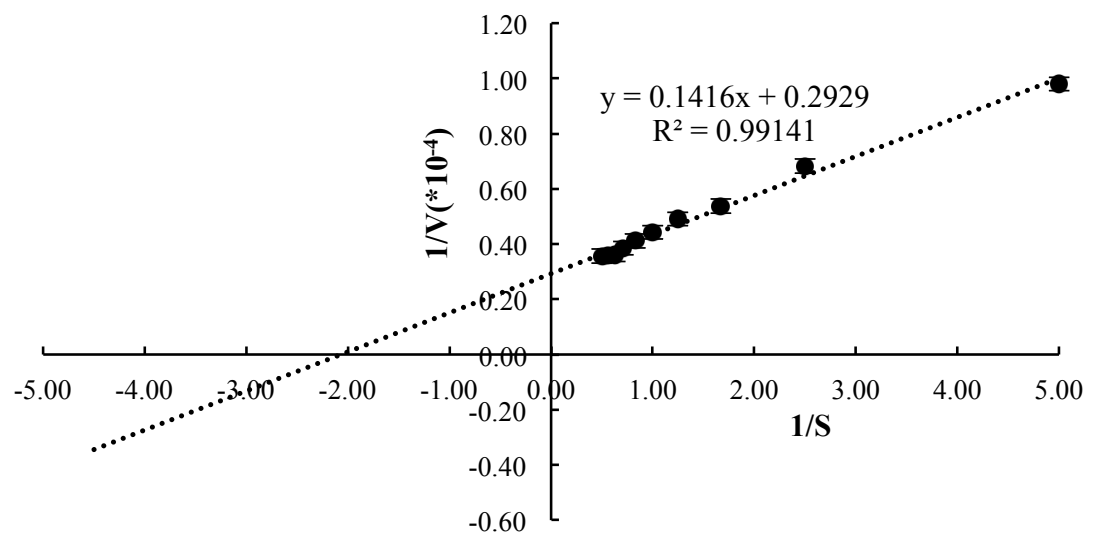

Figure 11: A Lineweaver Burk plot for the purified P. reinekei (H1) lipase using $p$ NP-Palmitate as substrate over the substrate concentration range $0.2-2 \mathrm{mM}$ under standard assay conditions. The data represented are the mean of three independent experiments and the standard deviations are noted as error bars.

\section{Substrate Specificity}

Lipase from $P$. reinekei $(\mathrm{H} 1)$ showed maximum catalytic efficiency for short chain $\left(\mathrm{C}_{8: 0}\right)$ Phenyl ester ( $p$ NP-Octanoate). The catalytic efficiency reduced with increased chain length from $\mathrm{C}_{10: 0}$ to $\mathrm{C}_{16: 0}$, with no, or minimal, catalytic activity observed for short chain esters $\left(\mathrm{C}_{2: 0}, \mathrm{C}_{4: 0}\right.$; Figure 12$)$.

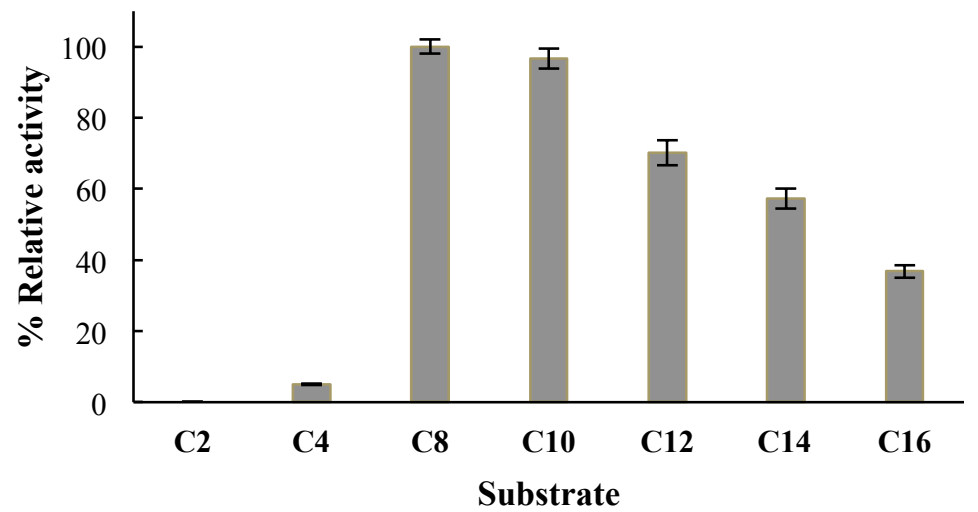

Figure 12: Substrate specificity of purified lipase from P. reinekei towards a range of $p$-NP esters. Specificity was mean of three independent experiments and the standard deviations are noted as error bars. 
Amino acid sequence identification

358 Mass spectrophotometer analysis of the purified lipase from $P$. reinekei revealed four conserved peptide 359 sequences: AGYTTAQVEVLGK; LLEIGIGFR; VLNIGYENDPVFR; ANTWVQDLNR. Internal 360 sequencing primers were designed to bind where these $P$. reinekei lipases peptide sequence fragments most closely aligned the lipase from P. fluorescens, Pseudomonas sp. PMAC 25886, P. yamanorum, LipAMS8 from Pseudomonas sp. AMS8 and Pseudomonas sp. PAMC25886 (Figure 13). Examination of phylogenetic tree of the amino acid sequences by BlastP in NCBI revealed the location of lipase from $P$. reinekei to other lipases of Pseudomonas species (Figure 14).

P. reinekei: H1

P. fluorescens

PAMC 25886

P. yamanorum

LipAMS 8

PTA-122608

P. reinekei: $\mathrm{H} 1$

P. fluorescens

PAMC 25886

P. yamanorum

LipAMS 8

PTA-122608

P. reinekei: $\mathrm{H} 1$

P. fluorescens

PAMC 25886

P. yamanorum

LipAMS 8

PTA-122608

P. reinekei: $\mathrm{H} 1$

P. fluorescens

PAMC 25886

P. yamanorum

LipAMS 8

PTA-122608

P. reinekei: H1

P. fluorescens

PAMC 25886

P. yamanorum

LipAMS 8

PTA-122608

P. reinekei: H1

P. fluorescens

PAMC 25886

P. yamanorum
MGVFDYKNLGTEGSKALFADAMAITLYSYHNLDNGFAVGYQHNGFGLGLPATLVGALLGS MGVFDYKNLGTEGSKALFADALAISLYSYHNLDNGFAVGYQHNGFGLGLPATLVGALLGS MGVFDYKNLGTEGSKALFADAMAITLYSYHNLDNGFAVGYQHNGFGLGLPATLVGALLGS MGVFDYKNLGTEGSKALFADAMAITLYSYHNLDNGFAVGYQHNGFGLGLPATLVGALLGS MGVFDYKNLGTEGSKALFADAMAITLYSYHNLDNGFAVGYQHNGFGLGLPATLVGALLGS

-----------------------------------------------------AGYTTAQ

TDSQGVIPGI PWNPDSEKAALDAVHKAGWTPISASTLGYGGKVDARGTFFGEKAGYTTAQ TDSQGVI PGI PWNPDSEKAALEAVNNAGWTP ISASTLGYGGKVDARGTFFGEKAGYTTAQ TDSQGVIPGI PWNPDSEKAALDAVNKAGWTPISASTLGYGGKVDARGTFFGEKAGYTTAQ TDSQGVIPGI PWNPDSEKAALEAVNKAGWTPISASTLGYGGKVDARGTFFGEKAGYTTAQ TDSQGVI PGI PWNPDSEKAALEAVNKAGWTP ISASTLGYGGKVDARGTFFGEKAGYTTAQ

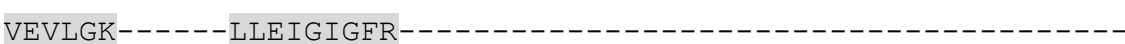
VEVLGKYDGDGKLLEIGIGFRGT SGPRETLISDSIGDLVSDLLAALGPKDYAKNYAGEAF VEVLGKYDGAGKLLEIGIGFRGTSGPRETLISDS I GDLVSDLLAALGPKDYAKNYAGEAF VEVLGKYDGAGKLLEIGIGFRGTSGPRETLITDS IGDLVSDLLAALGPKDYAKNYAGEAF VEVLGKYDGDGKLLEIGIGFRGTSGPRETLITDS I GDLVSDLLAALGPKDYAKNYAGEAF VEVLGKYDGDGKLLEIGIGFRGTSGPRETLITDS IGDLVSDLLAALGPKDYAKNYAGEAF

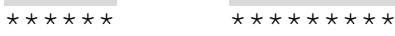

SMADLSGNKWSGFYKDSNYVAYASPT GTLLKDVAAYAGSHGLTGKDVVVSGHSLGGLAVNSMADLSGNKWSGFYKDSNYVAYASPT GTLLKDVAAYAGSHGLTGKDVVVSGHSLGGLAVNSMADLSGNKWSGFYKDSNYVAYASPT GTLLKDVAAYAGSHGLTGKDVVVSGHS LGGLAVNSMADLSGNKWSGFYKDSNYVAYASPT GTLLKDVAAYAGS HGLTGKDVVVSGHS LGGLAVNSMADLS GNKWSGFYKDSNYVAYASPT GTLLKDVAAYAGSHGLTGKDVVVSGHSLGGLAVNSMADLSGNKWSGFYKDSNYVAYASPT

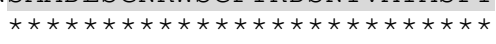

QSSAT-VLNIGYENDPVFR--------------------------------WNVL QSAGDKVLNIGYENDPVFRALDGSSFNFSS LGVHDKPHESTTDNIVSFNDHYASTLWNVL QSSGDKVLNIGYENDPVFRALDGSS FNFS S LGVHDKPHESTTDNIVNFNDHYASTLWNVL QS S GDKVLNIGYENDPVFRALDGSSFNFS S LGVHDKPHESTTDN IVNFNDHYASTLWNVL QSSGDKVLNI GYENDPVFRALDGSSFNFS S LGVHDKPHESTTDNIVS FNDHYASTLWNVL QSSGDKVLNIGYENDPVFRALDGSSFNFS S LGVHDKPHESTTDNIVS FNDHYASTLWNVL

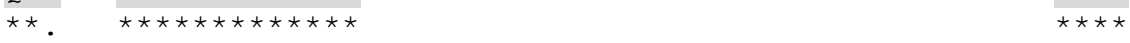

PFS IVNVPTWLSHLPTAYGDGLTRVLDSKFYDLTSRDS------------ANTWVQDLNR PFS IVNVPTW I SHLPTAYGDGLTRVLDSQFYDLTSRDST I IVANLS DPARANTWVQDLNR PFS IVNVPTWLSHLPTAYGDGLTRVLDSTFYDLTSRDST I IVANLS DPARANTWVQDLNR PFS IVNVPTWLSHLPTAYGDGLTRVLDSKFYDLTSRDST I IVANLS DPARANTWVQDLNR 
Figure 13: Alignment of P. reinekei (H1) lipase with lipase from P. fluorescens, Pseudomonas sp. PAMC 25886, $P$. yamanorum, LipAMS8 from Pseudomonas sp. AMS8 and Pseudomonas sp. PTA-122608.

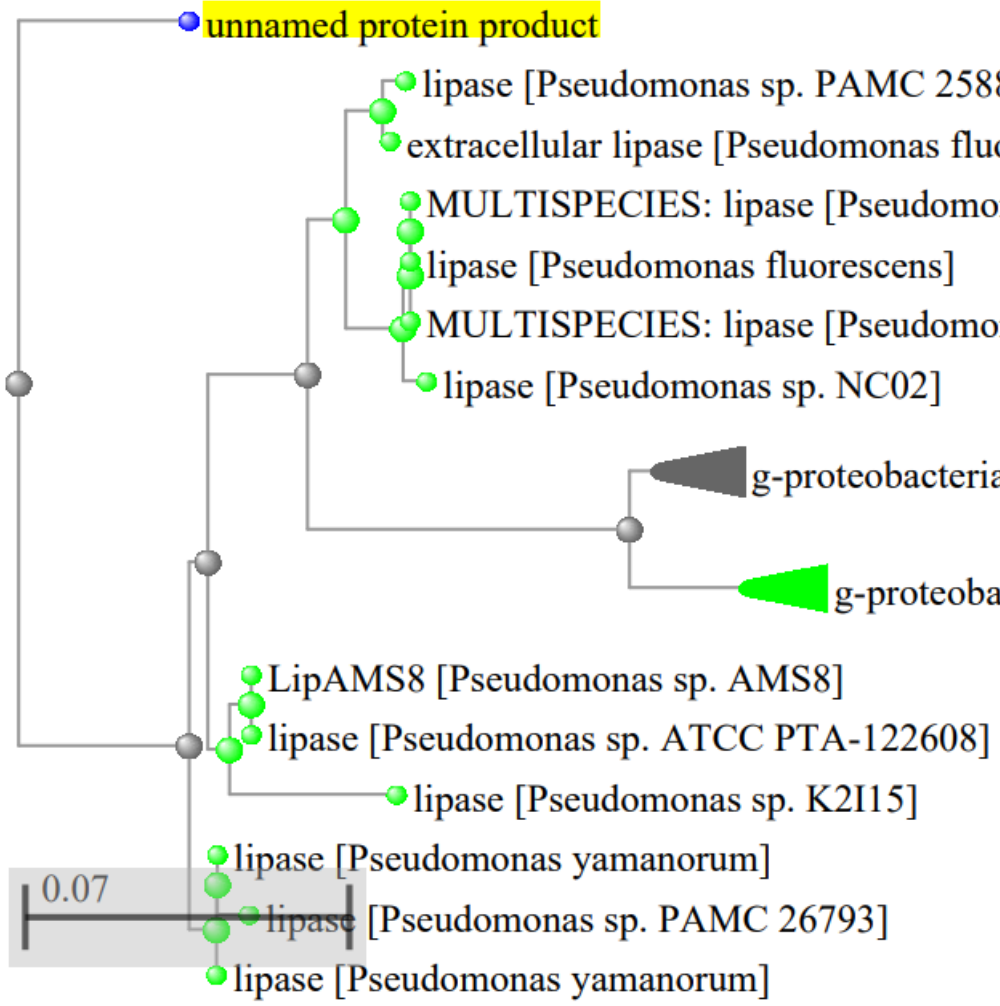

Figure 14: A distance tree based on conserved amino acid sequences in P. reinekei lipase generated via a BlastP alignment. The homology of $P$. reinekei lipase (highlighted in yellow and reported as 'unnamed protein product') to lipases from different Pseudomonas sp. is noted as within the same clade.

\section{Conclusion}


Pseudomonas sp. is one of the most studied bacterial species [51]; and lipases from these have been extensively explored. In this study, a novel lipase from $P$. reinekei was discovered and when fully characterised, displayed high stability in a variety of industrially relevant organic solvents. Furthermore, it was stable over wide $\mathrm{pH}$ range (5.0-9.0) and was moderately thermostable, suggesting that this enzyme may be a suitable candidate for bio-transformations in the food and pharmaceutical industries. Additionally, the novelty of $P$. reinekei strain, and the lipase explored here with its unique stability characteristics, makes this enzyme a potential catalyst for other biotechnological applications such as synthesis of biodiesel and biodegradable biopolymers. Further explorative work, including molecular cloning and lipase over expression, will assist in the application of this novel enzyme.

\section{Acknowledgement}

This research was funded by Fiosraigh Scholarship granted by Dublin Institute of Technology. We thank Dr. Paul Dowling from Maynooth University, Ireland for performing Mass Spectroscopy of the purified enzyme sample.

\section{References}

1. Romo, A. De. Tallow and the Time Capsule: Claude Bernard's Discovery of the Pancreatic Digestion of Fat. Hist. Philos. life Sci. 1989, 11 (2), 253-274. Available online: https://www.ncbi.nlm.nih.gov/pubmed/2700021

2. Karl-Erich Jaeger, Stéphane Ransac, Bauke W. Dijkstra, et al. Bacterial lipases. Microbiology Reviews. 1994, 15(1), 29-63. Available online: https://academic.oup.com/femsre/articleabstract $/ 15 / 1 / 29 / 482303$ ?redirectedFrom=fulltext

3. Bose, A.; Keharia, H. Production, Characterization and Applications of Organic Solvent Tolerant Lipase by Pseudomonas Aeruginosa AAU2. Biocatal. Agric. Biotechnol. 2013, 2 (3), $255-266$. Available https://www.sciencedirect.com/science/article/pii/S1878818113000339

4. Kumar, A.; Dhar, K. et. al. Lipase Catalysis in Organic Solvents: Advantages and Applications. Biol. Proced. Online 2016, 18(2). Available at: https://www.ncbi.nlm.nih.gov/pmc/articles/PMC4711063/

5. Qayed, W. S.; Aboraia, A. S. et. al. Lipases-Catalyzed Enantioselective Kinetic Resolution of Alcohols. Journal of Chemical and Pharmaceutical Research. 2015, 7 (5): 311-322. Available at: http://www.jocpr.com/articles/lipasescatalyzed-enantioselective-kineticresolution-of-alcohols.pdf

6. Wang, S.; Meng, X.et al.. Enzyme Stability and Activity in Non-Aqueous Reaction Systems: A Mini Review. Catalysts.2016, 6 (2), 32. Available at: http://www.mdpi.com/2073$\underline{4344 / 6 / 2 / 32}$

7. Kouker, G.; Jaeger, K. E. Specific and Sensitive Plate Assay for Bacterial Lipases. Appl. Environ. $\quad$ Microbiol. 1987, 53 (1), 211-213. Available at: https://www.ncbi.nlm.nih.gov/pmc/articles/PMC203632/

8. Glogauer, A.; Martini, V. P. et al. Identification and Characterization of a New True Lipase Isolated through Metagenomic Approach. Microb. Cell Fact. 2011, 10, 54. Available at: https://www.ncbi.nlm.nih.gov/pmc/articles/PMC3161859/pdf/1475-2859-10-54.pdf

9. Hospital, P.; Creu, S.; Pau, S. Direct Fluorescence-Based Lipase Activity Assay. Biotechniques $1999,27 . \quad$ Available at: 
https://www.researchgate.net/publication/12776861_Direct_fluorescence-

based_lipase_activity_assay

10. Mo, Q.; Liu, A. et al. A Novel Thermostable and Organic Solvent-Tolerant Lipase from Xanthomonas Oryzae Pv. Oryzae YB103: Screening, Purification and Characterization. Extremophiles. $2016, \quad 20 \quad$ (2), 157-165. Available at: https://link.springer.com/article/10.1007\%2Fs00792-016-0809-y

11. Patel, V.; Nambiar, S. et. al. An Extracellular Solvent Stable Alkaline Lipase from Pseudomonas Sp. DMVR46: Partial Purification, Characterization and Application in NonAqueous Environment. Process Biochem. 2014, 49 (10), 1673-1681. Available at: https://www.sciencedirect.com/science/article/pii/S1359511314003353

12. Kim, B., \& Gadd, G. Bacterial Physiology and Metabolism. Cambridge: Cambridge University. 2008. Press. doi:10.1017/CBO9780511790461

13. Andualema, B.; Gessesse, A. Microbial Lipase and Their Industrial Applications: Review. Biotechnology. 2012, 11(3),100-118. Available at: https://scialert.net/fulltextmobile/?doi=biotech.2012.100.118

14. Ayinla, Z. A.; Ademakinwa, A. N.et al. Studies on the Optimization of Lipase Production by Rhizopus Sp. ZAC3 Isolated from the Contaminated Soil of a Palm Oil Processing Shed. J. Appl. Biol. Biotechnol. 2017, 5 (02), 30-37. Available at: https://www.researchgate.net/profile/Zainab_Ayinla/publication/318216163_Studies_on_the_ Optimization_of_Lipase_Production_by_Rhizopus_sp_ZAC3_Isolated_from_the_Contamina ted_Soil_of_a_Palm_Oil_Processing_Shed/links/596a66c20f7e-9b80919464dē/Studies-onthe-Optimization-of-Lipase-Production-by-Rhizopus-sp-ZAC3-Isolated-from-theContaminated-Soil-of-a-Palm-Oil-Processing-Shed.pdf

15. Randa, A. A.; Rahman, R. N. Z. R.; et al. Optimization of Physical Factors Affecting the Production of Thermo-Stable Organic Solvent-Tolerant Protease from a Newly Isolated Halo Tolerant Bacillus Subtilis Strain Rand. Microb. Cell Fact. 2009, 8 (20). Available at: https://www.ncbi.nlm.nih.gov/pmc/articles/PMC2671491/

16. Gupta, V. K.; Sharma, G. D. et. al. The Handbook of Microbial Bioresources; 2016. Press. doi: 10.1079/9781780645216.0000

17. Sachan, S.; Singh, A. Production of Lipase by Pseudomonas Aeruginosa JCM5962 (T) Under Semi-Solid State Fermentation: Potential Use of Azadirachta Indica (Neem) Oil Cake. Biosci ence Biotechnol. Res. Asia. 2017, 14 (2), 767-773. Available at: http://www.biotechasia.org/vol14no2/production-of-lipase-by-pseudomonas-aeruginosa-jcm5962t-under-semisolid-state-fermentation-potential-use-of-azadirachta-indica-neem-oil-cake/

18. Joseph, B.; Upadhyaya, S. et al. Production of Cold-Active Bacterial Lipases through Semisolid State Fermentation Using Oil Cakes. Enzyme Res. 2011. Available at: https://www.hindawi.com/journals/er/2011/796407/

19. Chander, H.; Ranganathan, B. Role of Amino Acids on the Growth and Lipase Production of Streptococcus Faecalis. Experientia 1975, 31 (11), 1263-1975. Available at: https://link.springer.com/article/10.1007\%2FBF01945768

20. Al-Saleh, A. A.; Zahran, A. S. Synthesis of Extracellular Lipase by a Strain of Pseudomonas Fluorescens Isolated from Raw Camel Milk. Food Microbiol. 1999, 16 (2), 149-156. Available at: https://www.sciencedirect.com/science/article/pii/S0740002098902271

21. Alford, J. A.; Pierce, D. A. Production of Lipase by Pseudomonas Fragi in a Synthetic Medium. J. Bacteriol. 1963, 86 (1), 24-29. Available at: http://jb.asm.org/content/86/1/24.full.pdf + html

22. Talley K. \& Alexov E. On the pH-optimum of activity and stability of proteins. Proteins. 2010, 78(12), 2699-2706. Available at: https://www.ncbi.nlm.nih.gov/pmc/articles/PMC2911520/ 
23. Veerapagu, M.; Sankara Narayanan et. al. Screening Selection Identification Production and Optimization of Bacterial Lipase from Oil Spilled Soil. Asian J. Pharm. Clin. Res. 2013, 6 (SUPPL.3), 62-67. Available at: https://innovareacademics.in/journal/ajpcr/Vol6Supp13/155.pdf

24. Kulkarni, N.; Gadre, R. Production and Properties of an Alkaline, Thermophilic Lipase from Pseudomonas Fluorescens NS2W. J. Ind. Microbiol. Biotechnol. 2002, 28 (6), 344-348. Available at: https://link.springer.com/article/10.1038/sj/jim/7000254

25. Padhiar, J.; Das, A.; Bhattacharya, S. Optimization of Process Parameters Influencing the Submerged Fermentation of Extracellular Lipases from Pseudomonas Aeruginosa, Candida Albicans and Aspergillus Flavus. Pakistan J. Biol. Sci. 2011, 14 (22). Available at: https://www.ncbi.nlm.nih.gov/pubmed/22514878

26. Fatima, H.; Khan, N. Production and Partial Characterization of Lipase from Pseudomonas Putida. Ferment. Technol. 2015, 4 (1), 1-7. Available at: https://www.omicsonline.org/openaccess/production-and-partial-characterization-of-lipase-from-pseudomonas-putida-21677972-1000112.php?aid=59905

27. Ohtake, S.; Kita, Y.; Arakawa, T. Interactions of Formulation Excipients with Proteins in Solution and in the Dried State. Adv. Drug Deliv. Rev. 2011, 63 (13), 1053-1073. Available at: https://www.sciencedirect.com/science/article/pii/S0169409X11001852?via\%3Dihub

28. Qamsari, E. M.; Kasra, K. R.; Nejad, Z. M. Isolation and Identification of a Novel, LipaseProducing Bacterium Pseudomnas Aeruginosa KM110. Iran. J. Microbiol. 2011, 3 (2), 92-98. Available at: https://www.ncbi.nlm.nih.gov/pmc/articles/PMC3279805/

29. Ramani, K.; Kennedy, L. J. et. al. Purification, Characterization and Application of Acidic Lipase from Pseudomonas Gessardii Using Beef Tallow as a Substrate for Fats and Oil Hydrolysis. Process Biochem. 2010, 45 (10), 1683-1691. Available at: https://www.sciencedirect.com/science/article/pii/S1359511310002527

30. Salihu, A.; Alam, M. Z. Production and Applications of Microbial Lipases: A Review. Sci. Res. Essays 2012, 7 (30), 2667-2677. Available at: https://www.researchgate.net/publication/272170607_Production_and_applications_of_micro bial_lipases_A_review

31. Almeida A. F.; Tauk-Tornisielo S et al. Acid Lipase from Candida Viswanathii: Production, Biochemical Properties, and Potential Application. Biomed Res. Int. 2013. Available at: https://www.hindawi.com/journals/bmri/2013/435818/

32. Xiuling, J.; Shan, L.et al. Gene Cloning, Sequence Analysis and Heterologous Expression of a Novel Cold-Active Lipase from Pseudomonas Sp. PF16. Technol. Heal. care 2015, 23, S109-S117. Available at: https://www.ncbi.nlm.nih.gov/pubmed/26410312

33. Sharma, A. K.; Tiwari, R. P. et. al. Properties of a Thermostable and Solvent Stable Extracellular Lipase from a Pseudomonas Sp. AG-8. J. Basic Microbiol. 2001, 41 (6), 363366. Available at: https://onlinelibrary.wiley.com/doi/pdf/10.1002/15214028\%28200112\%2941\%3A6\%3C363\%3A\%3AAID-JOBM363\%3E3.0.CO\%3B2-C

34. Ahmed, E. H.; Raghavendra, T. et. al. An Alkaline Lipase from Organic Solvent Tolerant Acinetobacter Sp. EH28: Application for Ethyl Caprylate Synthesis. Bioresour. Technol. 2010, $101 \quad$ (10), 3628-3634. Available at: https://www.sciencedirect.com/science/article/pii/S0960852409018057

35. Sheldon, R. A.; Pereira, P. C. Biocatalysis Engineering: The Big Picture. Chem. Soc. Rev. 2017, $46 \quad$ (10), 2678-2691. Available at: http://pubs.rsc.org/en/content/articlelanding/2017/cs/c6cs00854b\#!divAbstract

36. Miranda M, Urioste D et. al. Assessment of the Morphological, Biochemical, and Kinetic Properties for Candida rugosa Lipase Immobilized on Hydrous Niobium Oxide to Be Used in the Biodiesel Synthesis. Enzyme Res. 2011, 16. Available at: https://www.ncbi.nlm.nih.gov/pmc/articles/PMC3157702/ 
37. Posner, I.; Morales, A. Mechanisms of Enzyme and Substrate Activation by Lipoprotein

Lipase Cofactors. J. Biol. Chem. 1972, 247 (8), 2255-2265. Available at: http://www.jbc.org/content/247/8/2255.long

38. Rukman, H.; Henny, W. Effect of Ca2+ Ion to the Activity and Stability of Lipase Isolated from Chromohalobacter Japonicus BK-AB18. Procedia Chem. 2015, 16, 306-313. Available at: https://www.sciencedirect.com/science/article/pii/S1876619615002053

39. Lee, S. Y.; Rhee, J. S. Production and Partial Purification of a Lipase from Pseudomonas Putida 3SK. Enzyme Microb. Technol. 1993, 15 (7), 617-623. Available at: https://www.sciencedirect.com/science/article/pii/014102299390026X

40. Parwata, I. P.; Asyari, M.; Hertadi, R. Organic Solvent-Stable Lipase from Moderate Halophilic Bacteria Pseudomonas Stutzeri Isolated from the Mud Crater of Bleduk Kuwu , Central Java , Indonesia. J. pure Appl. Microbiol. 2014, 8 (February), 1-10. Available at: https://www.researchgate.net/publication/260798594_Organic_Solvent-

Stable_Lipase_from_Moderate_Halophilic_Bacteria_Pseudomonas_stutzeri_Isolated_from_t he_Mü__Crater_of_Bleduk_Küwu_Central_Java_Indonesia

41. Monhemi, H.; Housaindokht, M. R. et al. How a Protein Can Remain Stable in a Solvent with High Content of Urea: Insights from Molecular Dynamics Simulation of Candida Antarctica Lipase B in Urea: Choline Chloride Deep Eutectic Solvent. Phys. Chem. Chem. Phys. 2014, No. $28 . \quad$ Available at: http://pubs.rsc.org/en/Content/ArticleLanding/2014/CP/c4cp00503a\#!divAbstract

42. Bofill, C.; Prim, N.; Mormeneo, M. et al. Differential Behaviour of Pseudomonas Sp. 42A2 LipC, a Lipase Showing Greater Versatility than Its Counterpart LipA. Biochimie 2010, 92 (3), 307-316. Available at: https://www.sciencedirect.com/science/article/pii/S0300908409003095?via\%3Dihub

43. Mogensen, J.; Sehgal P. et. al. Activation, Inhibition, and Destabilization of Thermomyces Lanuginosus Lipase by Detergents. Biochemistry 2005, 44 (5), 1719-1730. Available at: https://pubs.acs.org/doi/abs/10.1021/bi0479757

44. Salameh, M. A.; Wiegel, J. Effects of Detergents on Activity, Thermostability and Aggregation of Two Alkalithermophilic Lipases from Thermosyntropha Lipolytica. Open Biochem. $\quad$ J. 2010, 4, 22-28. Available at: https://www.ncbi.nlm.nih.gov/pmc/articles/PMC2847205/

45. Kubler, D.; Bergmann, A. et. al. Kinetics of Detergent-Induced Activation and Inhibition of a Minimal Lipase. J. Phys. Chem. B 2017, 121 (6), 1248-1257. Available at: https://pubs.acs.org/doi/abs/10.1021/acs.jpcb.6b11037

46. Ugur, A.; Sarac, N. et. al. New Lipase for Biodiesel Production: Partial Purification and Characterization of LipSB 25-4. ISRN Biochem. 2014. Available at: https://www.hindawi.com/journals/isrn/2014/289749/

47. Syed, M. N.; Iqbal, S. et. al. Purification and Characterization of $60 \mathrm{Kd}$ Lipase Linked with Chaperonin from Pseudomonas aeruginosa Bn-1. African J. Biotechnol. 2010, 9 (45), 77247732. Available at: https://www.ajol.info/index.php/ajb/article/view/130445

48. Bhunia, B.; Dey, A. Statistical Approach for Optimization of Physiochemical Requirements on Alkaline Protease Production from Bacillus Licheniformis NCIM 2042. Enzyme Res. 2012. Available at: https://www.hindawi.com/journals/er/2012/905804/

49. Ganasen, M.; Yaacob, N. et al. Cold-Adapted Organic Solvent Tolerant Alkalophilic Family I.3 Lipase from an Antarctic Pseudomonas. Int. J. Biol. Macromol. 2016, 92, 1266-1276. Available

at: https://www.sciencedirect.com/science/article/pii/S014181301630681X?via\%3Dihub

50. Cao, Y.; Zhuang, Y. et. al. Purification and Characterization of an Organic Solvent-Stable Lipase from Pseudomonas Stutzeri LC2-8 and Its Application for Efficient Resolution of (R, S)-1-Phenylethanol. Biochem. Eng. J. 2012, 64, 55-60. Available at: https://www.sciencedirect.com/science/article/pii/S1369703X12000733 
51. Novik, G.; Savich, V.; Kiseleva, E. An Insight Into Beneficial Pseudomonas Bacteria. In Microbiology in Agriculture and Human Health; 2015; pp 73-105. Available at: https://www.intechopen.com/books/microbiology-in-agriculture-and-human-health/aninsight-into-beneficial-pseudomonas-bacteria

630 